\title{
AVAlIAÇÃo dA PRODUÇÃo E QUALIDADE DO GÁS DE ATERRO PARA ENERGIA NO ATERRO SANITÁRIO DOS BANDEIRANTES - SP
}

\section{EVALUATION OF THE PRODUCTION AND QUALITY OF THE LANDFILL GAS TO ENERGY AT BANDEIRANTES LANDFILL - SP}

\begin{abstract}
TIAGO NASCIMENTO SILVA
Oceanógrafo (UNIVALI), Mestre em Ciência e Tecnologia Ambiental (UNIVALI) Gerente de Produção da Biogás Energia Ambiental S. A. Graduação em Oceanografia a pela Universidade do Vale do Itajaí. Mestrado em Ciência e Tecnologia Ambiental pela Universidade do Vale do Itajaí. Graduando em Engenharia Ambiental pela Universidade São Marcos

\section{LuCILA MARIa DE SOUZA CAMPOS}

Engenheira de produção materiais (UFSCAR). Mestre e Doutora em engenharia de produção (UFSC). Professora titular da UNIVALI, atuando nos cursos de graduação em Administração, Engenharia Ambiental e Engenharia Industrial Mecânica e na pós-graduação no Programa de Ciência e Tecnologia Ambiental e no Programa de Administração e Turismo
\end{abstract}

\section{Recebido: 13/02/07 Aceito: 18/02/08}

\section{RESUMO}

O presente trabalho apresenta os primeiros resultados da avaliação da produção e qualidade do gás para a geração de energia em um aterro sanitário. Foram monitorados parâmetros de qualidade do biogás, pressão exercida pelo sistema e volume de gás extraído. A partir do acompanhamento desses parâmetros, foram feitas três análises em diferentes situaçōes que pudessem explicar o comportamento dos parâmetros: uma análise com poços em diferentes profundidades e duas análises a caráter de comparação: (a) poços conectados ao sistema de captação por extração ativa; e (b) poços não conectados ao sistema de captação, com extração passiva. Os resultados demonstraram que poços em profundidade intermediária apresentam as maiores produções e qualidade do gás e poços com extração passiva em relação à ativa tiveram diferenças significativas dos parâmetros acompanhados.

PALAVRAS CHAVE: Biogás, aterro sanitário, metano, sistema de captação.

\begin{abstract}
The present work shows the initial results of the evaluation of production and quality of the landfill gas to energy. Parameters of quality, pressure exerted by the system and volume of extracted landfill gas had been monitored. From the accompaniment of these parameters, three different analyses in different situations could explain the behavior of the wells: one analysis of wells in different depths, and two comparison analyses: (a) wells hardwired to the system of collection for active extraction; and (b) wells not hardwired to the collection system, with passive extraction. The results demonstrated that wells at intermediate deep have the highest yields and quality of gas and wells with passive extraction in relation to the active ones had significant differences of the monitored parameters.
\end{abstract}

KEYWORDS: Biogas, landfill, methane, collection system.

\section{INTRODUÇÃO}

Durante o intervalo de 1950 a 1998, houve a duplicação dos Gases de Efeito Estufa (GEE) no mundo. Estes gases são capazes de reter o calor do sol, sem os quais a radiação solar se dissiparia no espaço, este fenômeno é chamado comumente de "efeito estufa". O efeito estufa é um fenômeno que ocorre de forma natural na atmosfera. Os GEE são essenciais, portanto, para manter a temperatura necessária para a existência de vida no planeta. Contudo, as atividades humanas e naturais que causam as alteraçôes ambientais vêm, ao longo dos anos, provocando mudanças climáticas em ritmos cada vez mais acelerados. A liberação de gases que causam o efeito estufa aumenta, a cada ano, uma vez que é produzida pela queima de combustíveis fósseis e de florestas, pelo mau uso das técnicas agrícolas e por gases emitidos pelo processo industrial. Em decorrência disso, a temperatura média do Planeta Terra teve um aumento médio entre 1,4 e 5 , $4{ }^{\circ} \mathrm{C}$ (IPCC (2001), EPA (2002)).

Por este motivo, recentemente, intensificou-se, no mundo inteiro, a busca por energias que liberem menos gases nocivos à atmosfera, levando em conta que as atuais formas de produção de energia trazem, quase sempre, um impacto negativo para o meio ambiente em sua totalidade.
Os gases que mais contribuem para os GEE são, por ordem de importância, os dióxidos de carbono, os CFC, o metano, o vapor de água, o ozônio e o óxido nitroso.

Uma das maiores fontes de emissões de metano são os aterros usados para a disposição de resíduos sólidos urbanos (RSU). O gás de aterro é produzido pela decomposição anaeróbica (sem a presença de oxigênio) de resíduos orgânicos. Este gás é composto por aproximadamente $50 \%$ de metano (CH4), 40\% de dióxido de carbono (CO2), 9\% de nitrogênio, e concentrações residuais de compostos orgânicos voláteis, poluentes perigosos e outros elementos. Como já mencionado 
anteriormente, o metano e o dióxido de carbono são considerados gases de efeito estufa; no entanto, o metano tem um potencial de aquecimento global 21 vezes superior ao do dióxido de carbono

Segundo IPCC (1996), a concentração de metano aumentou em 1060 ppb (partes por bilhão) desde 1750 . Esse número representa um aumento de $151 \%$ do total de emissões de metano no mundo, mais da metade é de origem antropogênica (aterros sanitários, agricultura de arroz, combustíveis fósseis e gado). Os aterros podem produzir de 6 a $20 \%$ desse total de metano.

Em função deste contexto, a captação e utilização do gás produzido em aterros é uma opção atrativa para a redução de gases do efeito estufa. Além disso, o metano possui uma grande energia contida nos seus átomos que faz com que o gás possa ser usado para a produção de energia elétrica através de sua combustão dentro de motogeradores que movem turbinas. Projetos deste tipo são de grande importância, pois diferentes fontes de energia alternativa podem diversificar ou incrementar a matriz energética atualmente existente, tais como a eólica, a solar, a biomassa e também a proveniente do biogás (EPA, 1996).

Dentro deste contexto, este artigo visa apresentar a avaliação da produção e qualidade do gás no Aterro dos Bandeirantes, um projeto pioneiro de aproveitamento do gás de aterro para a geração de energia.

\section{METODOLOGIA}

A pressão de sucção exercida nos poços do aterro é produzida por sopradores centrífugos localizados na Usina de Gás. Estes sopradores tem a função de extrair o gás do aterro e impulsiona-lo até as máquinas de geração de energia e o excesso deste gás até os queimadores. Os parâmetros de produção de gás e teor de metano foram coletados diariamente entre fevereiro e dezembro de 2005.

Foram feitas três diferentes análises, a saber:

- (1) Análise de perfis: Foram selecionados 26 poços com exaustão forçada e distância superiores a $20 \mathrm{~m}$ de raio entre si representando 9 (nove) perfis no maciço do aterro. Esses poços representam cortes verticais no aterro que proporciona uma comparação dos parâmetros coletados com a profundidade e, conseqüentemente, com a idade das camadas (Ver Figura 1). Para que estes "cortes" ou "perfis do maciço do aterro" pudessem ser mais bem representados foi selecionado um poço com uma profundidade maior (maior do que $30 \mathrm{~m}$ ), outro com uma profundidade intermediária (entre 30 e $20 \mathrm{~m}$ ) e outro com uma profundidade menor (20 a $0 \mathrm{~m}$ ). Os dados de profundidade dos poços foram retirados através do histórico do acompanhamento topográfico de cotas do terreno do aterro de acordo com a deposição das células de lixo (Fonte: Heleno \& Fonseca Construtécnica).

Esses nove perfis tiveram como objetivo estudar o comportamento dos parâmetros de pressão, produção e qualidade do gás em relação à profundidade, sendo que esta variável em um aterro sanitário está relacionada com a idade tendo em vista que as células de lixo foram dispostas em cima da outra, porém os dados de idade não foram determinados por falta de informação precisa. Os poços selecionados foram instalando cabeçotes de PEAD (polietileno de alta densidade) em cima de drenos verticais construídos desde a base do aterro através da metodologia de "Drenos de Ranzini" (Jaramillo, 1991)

- (2) análise de poços com extração passiva e ativa: Não havendo o sistema de coleta de biogás no local de estudo, o biogás drenado nos poços do aterro sairia para atmosfera de forma passiva, ou seja, sem ser forçado pela pressão negativa imposto pelo sistema. Esta sucção pode gerar um comportamento diferenciado no maciço em torno destes poços em relação a poços ligados ao sistema de captação relatado no presente trabalho.

Foram selecionados três poços para estudo e comparação do compor- tamento de poços sem a extração forçada, e os mesmos três poços (PB 123, $\mathrm{PB} 5 \mathrm{~A}$, e $\mathrm{PB}$ 134B) com a extração forçada. Esses poços foram monitorados diariamente sendo coletados os parâmetros de pressão, produção e qualidade do gás, para uma posterior comparação e discussão.

Para os poços com extração passiva, foi colocada uma estrutura chamada de "chaminé" onde os gases dos poços poderiam sair livremente para a atmosfera e também monitorados nas válvulas de medição (ver Figura 2).

(3) Análise de poços com extração ativa: Como dito anteriormente, foram selecionados os mesmos três poços da análise acima, mas esses poços foram conectados normalmente ao sistema, para a comparação com poços com extração passiva.

\section{Aparelhos utilizados}

Todos os aparelhos utilizados são comumente usados em aterros em todo mundo, assim como todos os aparelhos fazem medições instantâneas dos parâmetros, portanto não sendo necessária a análise em laboratório.

Para a medição do teor de meta-no e oxigênio em porcentagem foi usado o GA 94 da Geotechnical Instruments ${ }^{\circledR}$. Este aparelho faz leitura dos gases através de uma bomba interna que succiona o gás para uma câmera interna que através de infravermelho mede em $\%$ a quantidade de gás metano e seu erro máximo é de $\pm 3,0 \%$. Para medição de vazão do gás foi usado um aparelho que possui uma ponteira com uma hélice na ponta para se obter a velocidade do gás em $\mathrm{m} / \mathrm{s}$ e com este valor calcular a vazão. $\mathrm{O}$ anemômetro Mini Air Junior da Schiltknecht ${ }^{\circledR}$. Seu erro máximo é de $+/-0.5 \%$ (Figura 3).

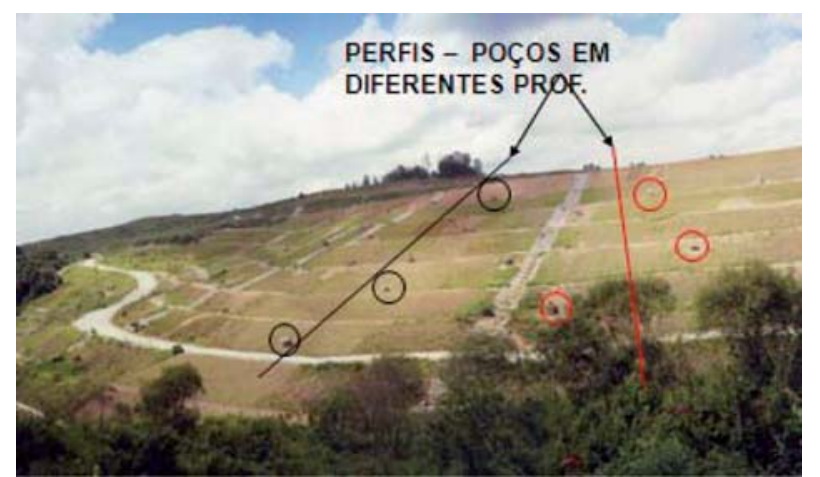

Figura I - Foto mostrando como foi selecionado os poços para o estudo de cortes 


\section{RESULTADOS}

\section{Análise de Perfis}

Produção dos poços captados

A análise geral mostrou que os poços usados para este estudo apresentaram uma vazão média de 81,99 N.m $3 /$ h (DP +/- 88,49). Quando verificada a vazão dos poços por estratificação de profundidade, encontram-se os seguintes resultados: (a) Os poços mais profundos tiveram uma vazão média de 77,77 N.m $3 /$ h (DP +/- 65,72); (b) Os poços intermediários tiveram uma vazão média de 103,38 N.m³/h (DP +/- 94,62); e (c) Os poços rasos tiveram uma vazão média de 50,30 N.m3/h (DP +/- 28,23). Portanto, os poços com profundidade intermediária $(30,00$ a 20,00 metros) apresentaram as maiores vazões de biogás registradas. Os acompanhamentos temporais das vazões instantânea dos 9 cortes estão apresentados na Figura 4.

Qualidade do gás

Para um melhor entendimento dos resultados da qualidade do gás, a análise foi dividida em análise do metano e análise do oxigênio.

\section{Metano}

A análise geral mostrou que os poços apresentaram uma porcentagem de metano média de 47,68\% (DP +/- 2,45). Quando verificada a porcentagem de metano no biogás extraído dos poços por estratificação de profundidade, encontra-se a seguinte relação: os poços mais profundos tiveram uma porcentagem de metano média de 45,47\% (DP +/- 5,93), os poços intermediários tiveram uma porcentagem de metano média de 51,74\% (DP +/-3,87) e os poços rasos tiveram uma porcentagem de metano média de 46,74\% (DP +/- 6,76). Os gráficos de acompanhamento do teor de metano ao longo do período estudado estão abaixo (Figura 5).

\section{Oxigênio}

A análise geral mostrou que os poços apresentaram uma porcentagem de oxigênio média de 1,26 \% (DP $+/$ - 0,41). Quando verificada a vazão dos poços por estratificação de profun-

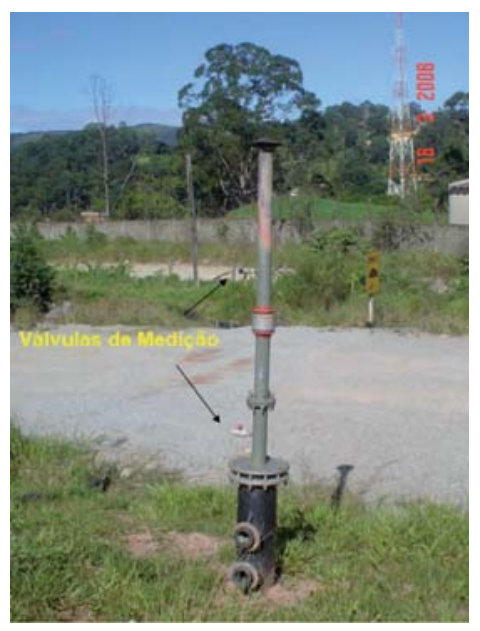

Fonte: Biogás Energia Ambiental S.A

Figura 2 - Foto da chaminé instalada em cima do poço de biogás para o estudo de poços com exaustão passiva
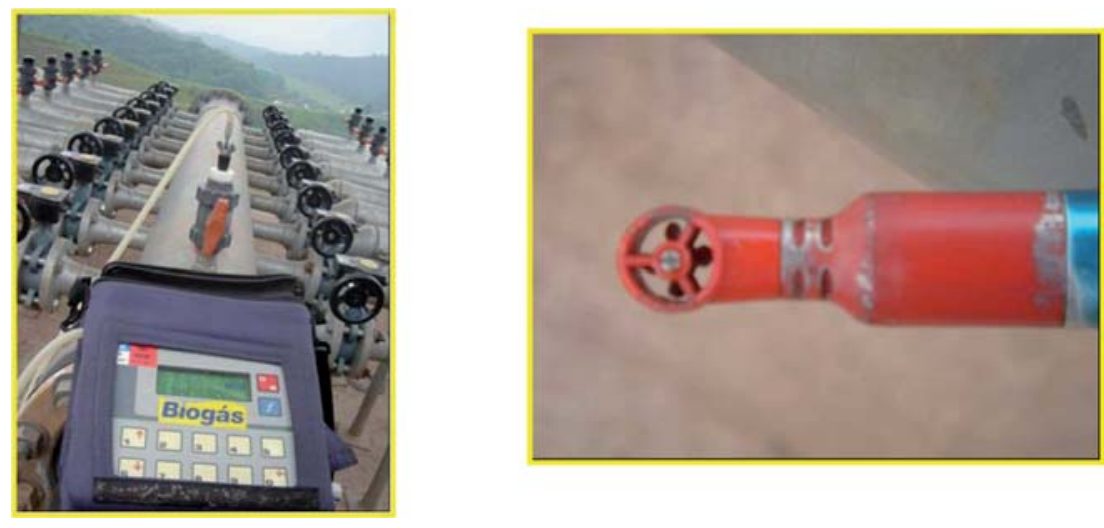

Fonte: Biogás Energia Ambiental S.A

Figura 3 - Fotos dos aparelhos usados para medição dos parâmetros no presente estudo. Da esquerda para a direita: analisador de gás e anemômetro

didade, encontra-se a seguinte relação: os poços mais profundos tiveram porcentagem de oxigênio média de 1,19\% (DP +/- 0,99), os poços intermediários tiveram porcentagem de oxigênio média de $0,73 \%(\mathrm{DP}+/-0,68)$ e os poços rasos tiveram porcentagem de oxigênio média de 1,68 \% (DP +/- 1,58). Os gráficos de acompanhamento do teor de oxigênio ao longo do período estudado estão abaixo (Figura 6).

\section{Comparação de poços com extração passiva $x$ poços com extração ativa}

Comparação da produção dos poços

De modo geral, os três poços analisados apresentaram uma vazão média em torno de $250 \mathrm{~N} . \mathrm{m}^{3} / \mathrm{h}$. Ambos também foram registrados grandes varia- çôes na vazão representadas pelo desvio padrão (DP) em relação à média.

Percebe-se que poços com extração ativa produzem vazão de biogás maior do que o medido com o sistema passivo. $\mathrm{O}$ poço $5 \mathrm{~A}$, por exemplo, apresenta uma diferença da média de vazão com sistema de extração passiva para a ativa de até cinco vezes mais $\left(295,52 \mathrm{~N} \cdot \mathrm{m}^{3} / \mathrm{h}\right.$ para o ativo e $54,69 \mathrm{~N} \cdot \mathrm{m}^{3} / \mathrm{h}$ para o passivo). Isto se deve ao fato de que poços com a extração ativa possuem uma área de influência no maciço de aterro muito maior do que poços com extração passiva (ver Tabela 1).

\section{Comparação do teor de metano}

Nota-se claramente que as médias dos valores de porcentagem de metano no biogás coletado por extração ativa são bem abaixo das médias dos com 


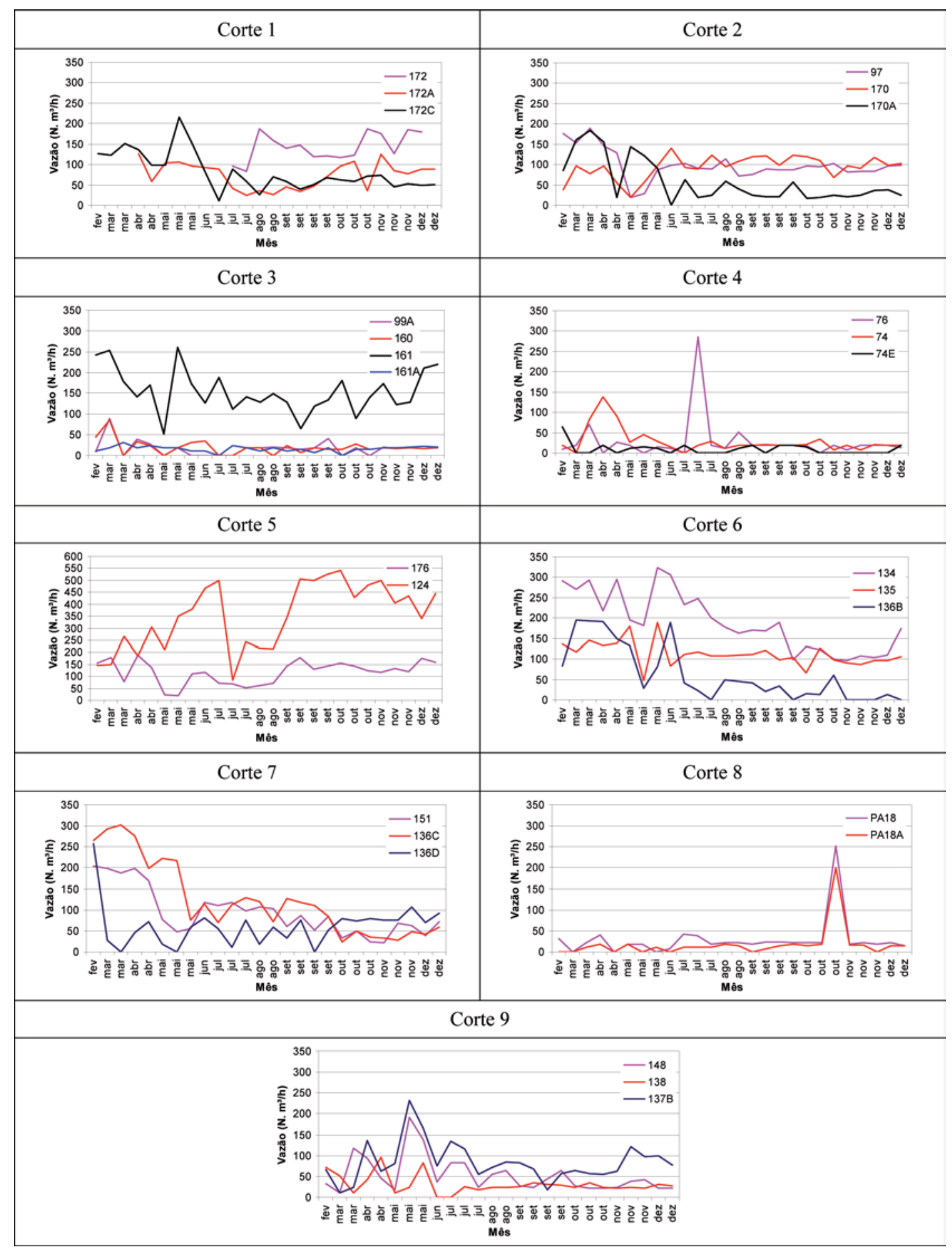

Figura 4 - Gráficos de acompanhamento das vazões instantâneas (N.m³/h) dos poços estudados na análise de cortes no período de fevereiro de 2005 a dezembro de 2005 . A legenda acompanha a estratificação por profundidade (profundos (de cima), intermediários (do meio) e rasos (último) 

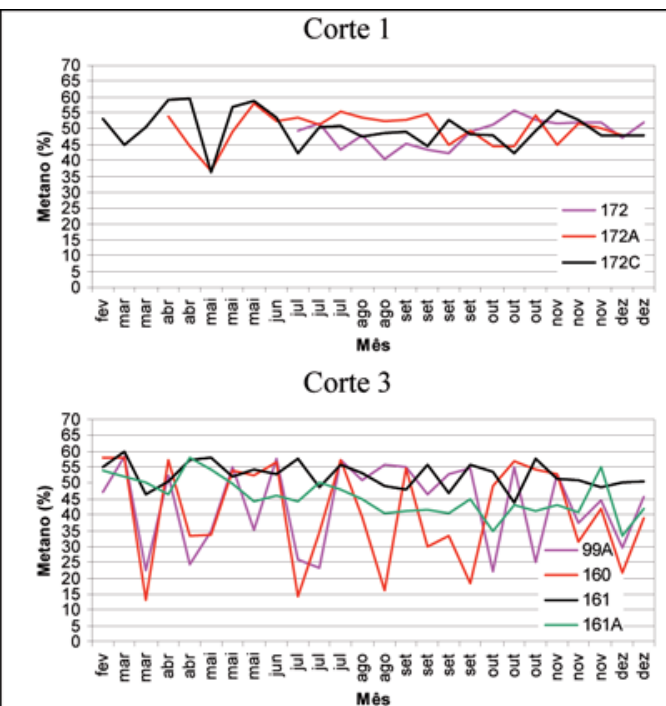

Corte 5

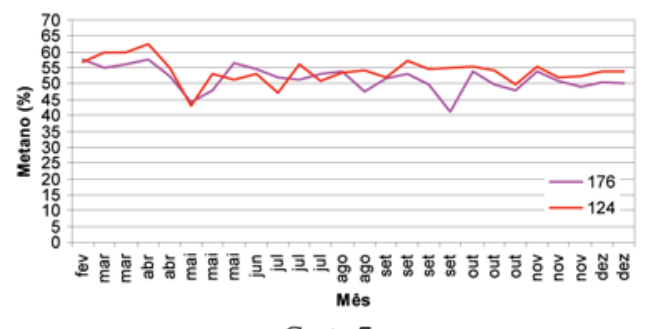

Corte 7

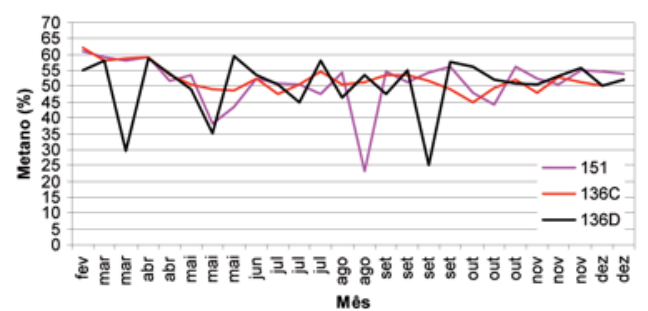

Corte 2

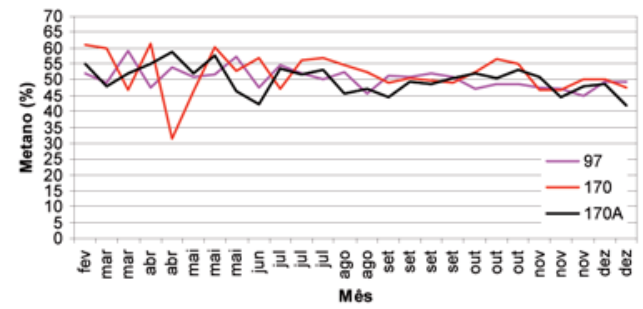

Corte 4

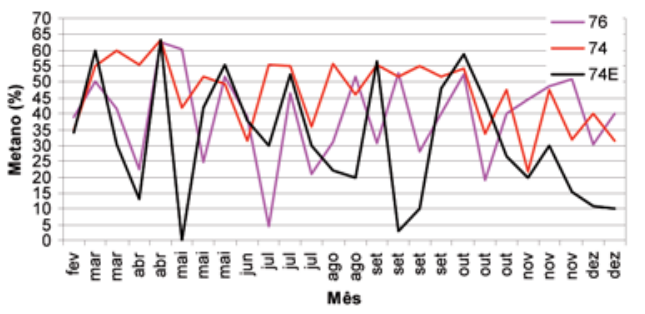

Corte 6
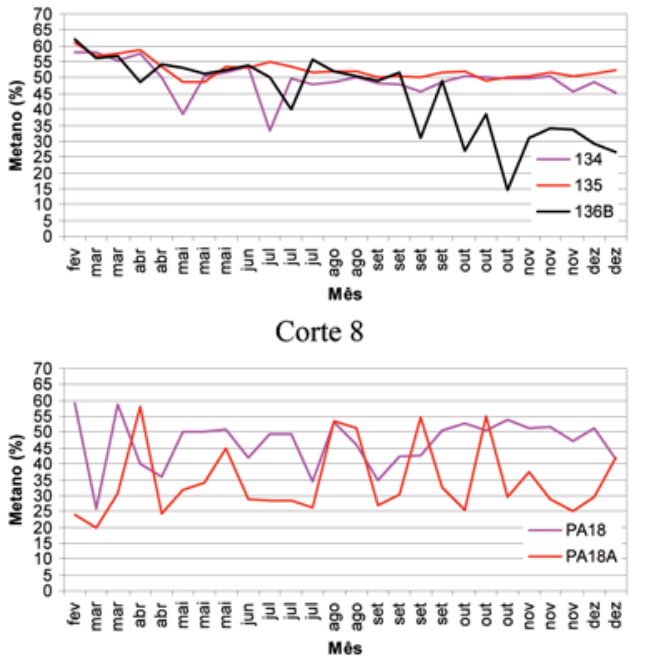

Corte 9

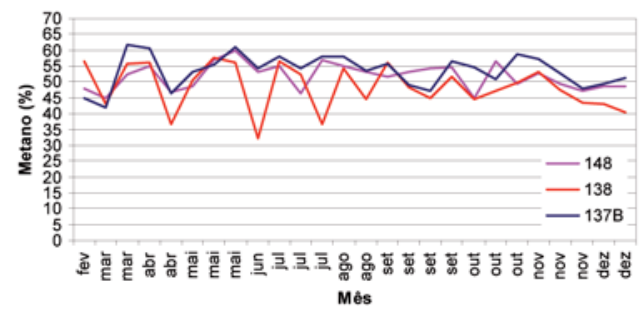

Figura 5 - Gráficos de acompanhamento das vazões instantâneas (N.m³/h) dos poços estudados na análise de cortes no período de fevereiro de 2005 a dezembro de 2005 .

A legenda acompanha a estratificação por profundidade (profundos (de cima), intermediários (do meio) e rasos (de baixo) 


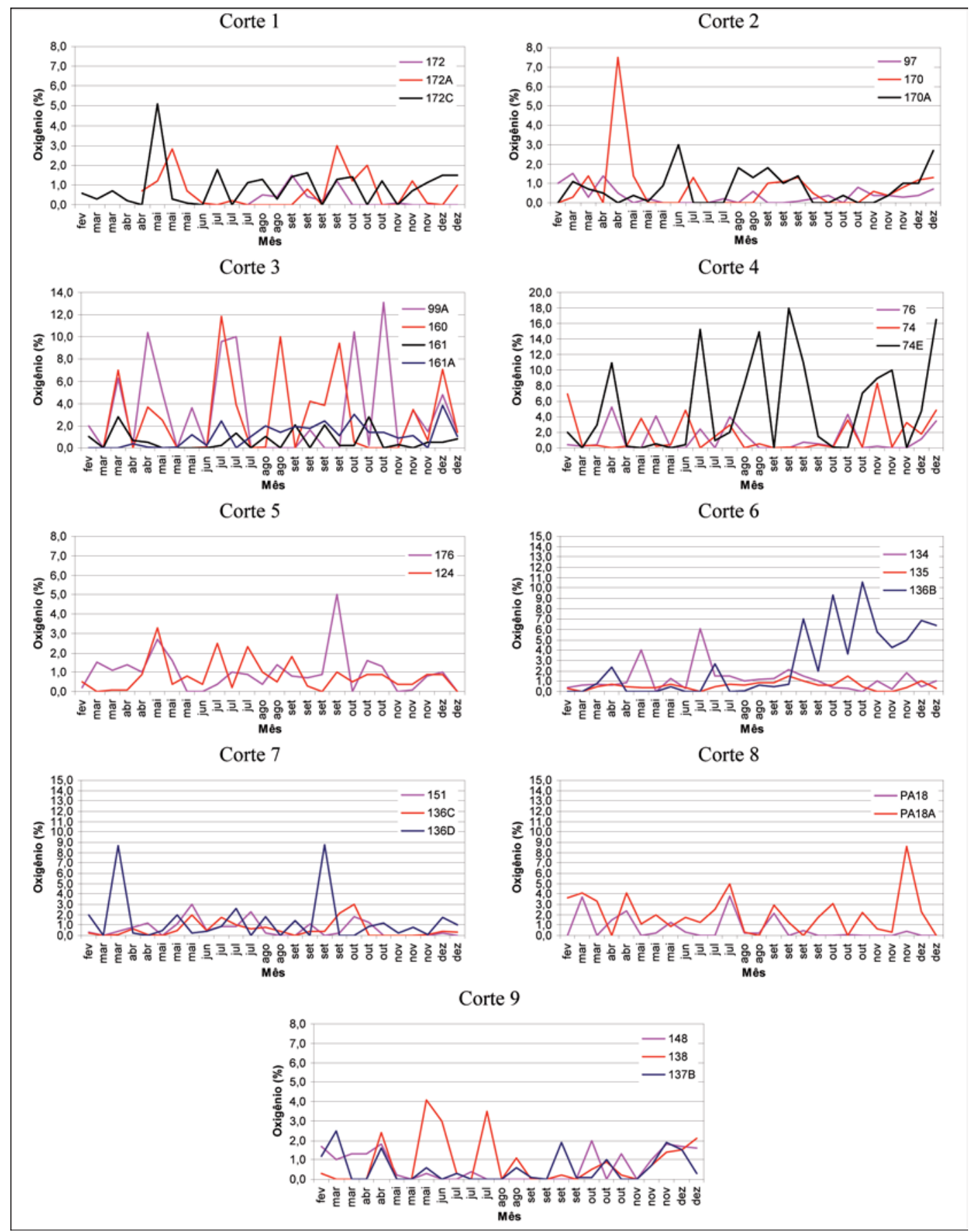

Figura 6 - Gráficos de acompanhamento do teor de metano (\%) dos poços estudados na análise de corte no período de fevereiro de 2005 a dezembro de 2005.

A legenda acompanha a estratificação por profundidade (profundos (de cima), intermediários (do meio) e rasos (de baixo) 
extração passiva, com exceção do poço 123 que variou relativamente pouco comparado com os outros poços (Tabela 2). O poço $134 \mathrm{~B}$ teve uma diminuição da média do metano de $57,83 \%$ (passiva) para 51,83 (ativa). O poço $5 \mathrm{~A}$ teve uma diminuição da média do metano de $57,65 \%$ (passiva) para 52,22 (ativa) (Tabela 2).

\section{Comparação do teor de oxigênio}

Apesar do valor de teor de oxigênio ser maior nos poços com extração ativa a diferença não foi significativa em termos operação do sistema. O valor de teor de oxigênio de até 3\% é aceitável em projetos de aproveitamento do biogás de aterro deste tipo, pois não afeta o funcionamento da Usina de Gás nem da Usina de Geração. Valores acima disso tornam-se perigosos por tornarem uma mistura explosiva (Tabela 3).

\section{DISCUSSÃO}

Os resultados deste trabalho indicam que a produção de gás de um poço do aterro sanitário em questão não depende somente de fatores favoráveis à degradação anaeróbica e sim das condiçôes do sistema de drenagem do aterro além de fatores ambientais externos.

As grandes variaçôes observadas nos gráficos de acompanhamento de vazão dos poços captados indicam a existência de rotas preferenciais de drenagem do gás devido à presença de drenos horizontais interligados nos poços de escoamento de chorume que podem ocasionar o entupimento dos mesmos. Fenômeno semelhante foi verificado por Ensinas (2003) que acompanhou a emissão de biogás de poços no aterro do Delta Campinas - SP, aterro que possui características físicas de engenharia bastante semelhantes ao Aterro dos Bandeirantes.

É importante salientar que a vazão dos poços ligados ao sistema de captação é regulada pela qualidade do gás no monitoramento. $\mathrm{O}$ procedimento de monitoramento dos poços deste projeto previa que poços com porcentagem menor que $50 \%$ de metano fossem fechados progressivamente até que teor de metano voltasse ao patamar de $50 \%$ ou mais. Poços que, por algum motivo não voltasse a patamares aceitáveis de qualidade, eram fechados pela válvula de controle e verificados na ocasião de monitoramento seguinte.

Tabela I - Tabela comparativa de vazão dos poços de extração obtidos na análise de poços com extração ativa e passiva

\begin{tabular}{cccc}
\hline \multicolumn{2}{c}{ Poços com extração ativa } & \multicolumn{2}{c}{ Poços com xtração passiva } \\
\hline Poço - 5A & Vazão $\left(\mathrm{N} \cdot \mathrm{m}^{3} / \mathrm{h}\right)$ & Poço - 5A & Vazão $\left(\mathrm{N} \cdot \mathrm{m}^{3} / \mathrm{h}\right)$ \\
Média & 295,52 & Média & 54,69 \\
Desvio padrão & 48,57 & Desvio madrão & 11,07 \\
Valor máximo & 367,35 & Valor máximo & 73,59 \\
Valor mínimo & 168,26 & Valor mínimo & 24,63 \\
Poço - 134B & Vazão $\left(\mathrm{N} \cdot \mathrm{m}^{3} / \mathrm{h}\right)$ & Poço - 134B & Vazão $\left(\mathrm{N} . \mathrm{m}^{3} / \mathrm{h}\right)$ \\
Média & 221,44 & Média & 26,85 \\
Desvio padrão & 65,12 & Desvio Padrão & 5,99 \\
Valor máximo & 325,70 & Valor máximo & 37,63 \\
Valor mínimo & 85,37 & Valor mínimo & 11,97 \\
Poço - 123 & Vazão $\left(\mathrm{N} . \mathrm{m}^{3} / \mathrm{h}\right)$ & Poço - 123 & Vazão $\left(\mathrm{N} . \mathrm{m}^{3} / \mathrm{h}\right)$ \\
Média & 207,67 & Média & 76,39 \\
Desvio padrão & 32,51 & Desvio padrão & 12,84 \\
Valor máximo & 270,47 & Valor máximo & 100,92 \\
Valor mínimo & 108,30 & Valor mínimo & 49,61 \\
\hline
\end{tabular}

Tabela 2 - Tabela comparativa de teor de metano (\%) dos poços de extração obtidos na análise de poços com extração ativa e passiva

\begin{tabular}{cccc}
\hline \multicolumn{2}{c}{ Poços com extração ativa } & \multicolumn{2}{c}{ Poços com extraçao passiva } \\
\hline Poço - 5A & $\mathrm{CH}_{4}(\%)$ & Poço - 5A & $\mathrm{CH}_{4}(\%)$ \\
Média & 52,22 & Média & 57,65 \\
Desvio padrão & 2,75 & Desvio padrão & 1,65 \\
Valor máximo & 56,70 & Valor máximo & 63,30 \\
Valor mínimo & 45,10 & Valor mínimo & 54,80 \\
Poço - 134B & $\mathrm{CH}_{4}(\%)$ & Poço - 134B & $\mathrm{CH}_{4}(\%)$ \\
Média & 51,83 & Média & 57,88 \\
Desvio padrão & 3,41 & Desvio padrão & 1,22 \\
Valor máximo & 58,40 & Valor máximo & 60,10 \\
Valor mínimo & 43,60 & Valor mínimo & 54,70 \\
Poço - 123 & $\mathrm{CH}, \%)$ & Poço - 123 & $\mathrm{CH}_{4}(\%)$ \\
Média & 55,80 & Média & 56,98 \\
Desvio padrão & 1,51 & Desvio padrão & 1,16 \\
Valor máximo & 58,80 & Valor máximo & 58,80 \\
Valor mínimo & 50,50 & Valor mínimo & 53,80 \\
\hline
\end{tabular}

Foi observado em poços do Corte 2, 4, 6 e 9 uma tendência de queda do teor de metano com o passar do tempo. Este fenômeno é comum, pois se sabe que em condições normais a taxa de decomposição atinge um pico entre o primeiro e segundo ano e diminui continuamente por mais 25 anos (Tcho- banglous, Theisen \& Vinil, 1993). Esta análise compreendeu um período de 11 meses, porém pode ter abrangido as fases finais de decomposição a qual resulta a um menor teor de metano medido no biogás, em função da drenagem do gás do poço vertical passar por células dispostas a mais de 8 anos no local. 
Tabela 3 - Tabela comparativa de teor de oxigênio (\%) dos poços de extração obtidos na análise de poços com extração ativa e passiva

\begin{tabular}{cccc}
\hline \multicolumn{2}{c}{ Poços com extração ativa } & \multicolumn{2}{c}{ Poços com extraçao passiva } \\
\hline Poço - 5A & $\mathrm{O}_{2}(\%)$ & Poço - 5A & $\mathrm{O}_{2}(\%)$ \\
Média & 1,08 & Média & 0,10 \\
Desvio padrão & 0,71 & Desvio padrão & 0,12 \\
Valor máximo & 2,80 & Valor máximo & 0,30 \\
Valor mínimo & 0,00 & Valor mínimo & 0,00 \\
Poço - 134B & $\mathrm{O}_{2}(\%)$ & Poço - 134B & $\mathrm{O}_{2}(\%)$ \\
Média & 0,99 & Média & 0,10 \\
Desvio padrão & 0,75 & Desvio padrão & 0,13 \\
Valor máximo & 2,70 & Valor máximo & 0,40 \\
Valor mínimo & 0,00 & Valor mínimo & 0,00 \\
Poço - 123 & $\mathrm{O}_{2}(\%)$ & Poço - 123 & $\mathrm{O}_{2}(\%)$ \\
Média & 0,04 & Média & 0,04 \\
Desvio padrão & 0,10 & Desvio padrão & 0,06 \\
Valor máximo & 0,50 & Valor máximo & 0,20 \\
Valor mínimo & 0,00 & Valor mínimo & 0,00 \\
\hline
\end{tabular}

Pelo fato de os poços estarem ligados a drenos horizontais de drenagem do chorume, alguns podem ter sido afetado por bolsões de chorume que ficam instalados no maciço do aterro. As primeiras fases da decomposição geram sub-produtos ácidos e as bactérias metanogênicas vivem somente em locais com pH neutro. Quando o percolado (chorume) submerge em algum poço ocasiona a redução da qualidade do gás por exterminar a população de bactérias metanogênicas. A presença de chorume em poços que reduziram drasticamente a produção e a qualidade do biogás foi verificada em diversos pontos na área de estudo do presente trabalho (Pohland, 1985)

Amostras com a presença de oxigênio indicam a presença de ar atmosférico no material analisado (Usdoe, 1983). No caso de poços com extração ativa, o oxigênio existente pode vir de três formas: (a) da atmosfera através da sucção por trincas e fissuras existentes em volta do poço; (b) por rompimento da tubulação ou flanges mal apertados; e (c) poços localizados ao lado de drenagens de águas pluviais.

\section{CONCLUSÃO}

O estudo mostrou que não há, para o caso do aterro em questão, com alturas de resíduos sólidos urbanos que ultrapassam os 100 metros, uma relação direta de poços mais profundos com a qualidade e produção de biogás. Poços com uma profundidade intermediária (20 - 30 metros) tiveram os maiores vazôes e teor de metano do gás extraído.

Nos fatores que podem justificar essa condição, apontam-se as grandes movimentaçóes do aterro, que devem afetar os drenos verticais e horizontais internos, tendo por conseqüência um caminhamento diferenciado do biogás, implicando uma captação não diretamente relacionada às profundidades perpassadas. Em função dessa condição, parte do biogás pode estar se redirecionando por meio do sistema de drenagem interna para caminhamentos que não essencialmente a dos próprios drenos verticais específicos. Nessas condições, o biogás não necessariamente resulta presente na totalidade dos drenos verticais, mas caminhando-se preferencialmente para determinadas regióes específicas, tornando, desse modo, vital para o sucesso da captação o pleno entendimento da logística e projeto de drenagem interna associada, além das condições de distribuição piezométrica inerente.

Os poços com extração ativa, em comparação com poços com extração passiva, demonstraram diferenças significativas nos valores dos parâmetros acompanhados. Os resultados indica- ram que poços com extração ativa afetam, de forma clara, regióes do maciço do aterro em seu entorno imediato. Isso é evidenciado pela grande diferença nas médias de produção e qualidade do biogás dos poços com extração ativa em relação a poços com extração passiva. Outro indício deste fenômeno é a presença de oxigênio nos poços com extração ativa, o que indica que o ar atmosférico está sendo succionado por trincas ou fissuras encontradas no aterro. Portanto, as condiçōes de impermeabilização do aterro e do sistema de drenagem passam a ser variáveis importantes no monitoramento do sistema de captação de biogás de um aterro sanitário.

O monitoramento do sistema de coleta de gás por meio do acompanhamento de parâmetros de pressão, qualidade e produção dos poços é instrumento fundamental. Um funcionamento não adequado desse sistema em relação ao potencial de cada região prospectada pode acarretar migrações heterogêneas e inadequadas, com perdas difusas do gás, por trincas e fissuras no aterro, ou uma indesejada inserção de oxigênio da atmosfera no sistema.

A metodologia do diagnóstico do sistema de captação se mostrou eficiente para o projeto do estudo de caso em questão pelo fato de se colher informações essenciais para decisōes por parte da operação do aterro e operação da usina de captação e geração de energia, principalmente pelo fato de o empreendimento constituir-se pioneiro, principalmente nessa envergadura, no País.

As maiores dificuldades encontradas no monitoramento do sistema de captação foram: (1) o acúmulo de condensado nas tubulações, principalmente nas secundárias que tem o diâmetro menor, que fazem com que, em muitos casos, o biogás não consiga passar pela tubulação; (2) administrar da qualidade do gás em função das variações climáticas diárias e sazonais; (3) o monitoramento dos poços instalados em um aterro ainda em operação, devido a constantes solicitações de mudanças de planos de instalação dos poços; e (4) a identificação da localização de rompimentos nas tubulações de PEAD devido a movimentos do maciço do aterro e oscilações da temperatura ambiente.

A forma ideal de captação do biogás de um poço com extração ativa 
é retirar-se o máximo de gás possível sem, entretanto, afetar o maciço do aterro do ponto de vista geotécnico e do potencial de geração intrínseca, região a região. Uma captação de forma não adequada pode acarretar no aumento da perda do biogás para a atmosfera, assim como encurtar o tempo de extração potencial do poço quando se afeta a vida bacteriana envolvida nas regiões de entorno de influência.

\section{AGRADECIMENTO}

Agradeço a todos que colaboraram para este trabalho e a toda equipe da Biogás Energia Ambiental S.A.

\section{REFERÊNCIAS}

ENSINAS, V. A. Estudo da Geração de Biogás no Aterro Sanitário Delta de Campinas-SP, Dissertação (Mestrado) - Faculdade de Engenharia Mecânica - Universidade Estadual de Campinas, 190p. 2003.

EPA, U. E. P. A. Turning a Liability into as asset: A Landfill Gas-to-energy Project Development Handbook. USA Environmental Protection Agency - EPA. 1996.

EPA. Solid Waste Management's and Green House Gases - A Life-Cycle Assessment of Emissions and Sinks, US. EPA. 2002.
INTERGOVERNMENTAL PANEL ON CLIMATE CHANGE - IPCC. Climate Change 2001: the scientific basis. HOUGHTON, J.T. et al. Cambridge University Press, 881p.2001.

INTERNATIONAL PANEL ON CLIMATE CHANGE (IPCC). Guidelines for National Greenhouse Inventories: Reference Manual (Vol.3). 1996. Disponível em: http://www.ipcc-ngip.iges. or.jp/public/gl/invs6. Acesso em 12/12/2005.

JARAMILLO, J. Resíduos sólidos municipales: guia para el diseño, construccion y operacion de rellenos sanitários manuales. Washington: Pan American Health Organization, 214 p. (Serie Técnica, 28). 1991.

POHLAND, F.G. et al. Leachate generation and control at landfill disposal sites. Water Poll. Res. J. Canadá., v.20, n³, p.10-24. (1985).

TSCHOBANOGLOUS, G.; THEISEN, H. \& VINIL, S. Integrated solid waste management. Engineering principles and management issues. Irwin MacGraw-Hill. 978p. 1993.

UNITED STATES DEPARTAMENT OF ENERGY (USDOE). Feasibility Study: Utilization of landfill gas for a vehicle fuel system - Rossmam's Landfill, Clackamas County, Oregon. Assistant secretary, conservation and renewable energy. Office of renewable technology. Washington, D. C. DOE/RA/50366-1. 1983.

\section{Endereço para correspondência:}

Tiago Nascimento Silva

Biogás Energia Ambiental S.A.

Rua Mogeiro, 1580

Bairro Perus

05206-240 São Paulo - SP - Brasil

Email: tiagon@biogas-ambintal.com.br 